\title{
Summary of the National Advisory Committee on Immunization (NACl) Statement on Seasonal Influenza Vaccine for 2016-2017
}

\author{
Gemmill I1,2, Zhao $L^{3}$, Cochrane $L^{3}$ on behalf of the National Advisory Committee on \\ Immunization (NACl) $)^{4, *}$
}

\section{Abstract}

Background: Influenza is a respiratory infection caused primarily by influenza A and B viruses. Vaccination is the most effective way to prevent influenza and its complications. The National Advisory Committee on Immunization (NACl) provides recommendations regarding seasonal influenza vaccines annually to the Public Health Agency of Canada (the Agency).

Objective: To summarize the $\mathrm{NACl}$ recommendations regarding the use of seasonal influenza vaccines for the 2016-2017 influenza season.

Methods: Annual influenza vaccine recommendations are developed by NACl's Influenza Working Group for consideration and approval by NACl, based on NACl's evidence-based process for developing recommendations, and include a consideration of the burden of influenza illness and the target populations for vaccination; efficacy and effectiveness, immunogenicity and safety of influenza vaccines; vaccine schedules; and other aspects of influenza immunization. These recommendations are published annually on the Agency's website in the NACl Advisory Committee Statement: Canadian Immunization Guide Chapter on Influenza and Statement on Seasonal Influenza Vaccine (the Statement).

Results: The annual $\mathrm{NACl}$ seasonal influenza vaccine recommendations have been updated for the 2016-2017 influenza season to include adults with neurologic or neurodevelopment conditions among the groups for whom influenza vaccination is particularly recommended; to include the new high-dose, trivalent inactivated influenza vaccine for use in adults 65 years of age and older; to recommend that egg-allergic individuals may also be vaccinated against influenza using the low ovalbumin-containing live attenuated influenza vaccine (LAIV) licensed for use in Canada ( $\mathrm{NACl}$ has previously recommended that egg-allergic individuals may be vaccinated using inactivated influenza vaccines); and to remove the preferential recommendation for the use of LAIV in children 2-17 years of age. Two addenda to the 2016-2017 Statement address these new LAIV recommendations.

Conclusion: $\mathrm{NACl}$ continues to recommend annual influenza vaccination for all individuals aged six months and older, with particular focus on people at high risk of influenza-related complications or hospitalization, people capable of transmitting influenza to those at high risk and others as indicated.
Affiliations

${ }^{1}$ Chair, National Advisory

Committee on Immunization

${ }^{2}$ Kingston, Frontenac and Lennox \& Addington Public Health, Kingston, ON

${ }^{3}$ Centre for Immunization and Respiratory Infectious Diseases, Public Health Agency of Canada, Ottawa, ON

${ }^{4} \mathrm{NACl}$ membership provided in Acknowledgements

*Correspondence: naci-ccni@ phac-aspc.gc.ca

Suggested citation: Gemmill I, Zhao L, Cochrane L on behalf of the National Advisory Committee on Immunization (NACl). Summary of the National Advisory Committee on Immunization (NACl) Statement on Seasonal Influenza Vaccine for 2016-2017. Can Comm Dis Rep 2016;42:188-92. https://doi.org/10.14745/ ccdr.v42i09a06

\section{Introduction}

Influenza is ranked among the top 10 leading causes of death in Canada (1). Although the burden of influenza can vary from year to year, it is estimated that, in a given year, there are an average of 12,200 hospitalizations related to influenza (2) and approximately 3,500 deaths attributable to influenza (3). The National Advisory Committee on Immunization (NACl) provides recommendations regarding seasonal influenza vaccines annually to the Public Health Agency of Canada (the Agency). NACl recommendations for the use of seasonal influenza vaccine for the 2016-2017 influenza season is summarized below. Complete details can be found in the Statement on Seasonal Influenza Vaccine for 2016-2017 (4), which includes the Canadian Immunization Guide Chapter on Influenza (Section II of the Statement) and in the two addenda to the Statement $(5,6)$ published on the Agency's website. 


\section{Methods}

In order to prepare the 2016-2017 seasonal influenza vaccine recommendations, NACl's Influenza Working Group (IWG) identified and reviewed evidence regarding adults with neurologic or neurodevelopment conditions as a risk group for complications of influenza; the new high-dose, trivalent inactivated influenza vaccine licensed for use in adults 65 years of age and older (Fluzone ${ }^{\circledR}$ High-Dose [Sanofi Pasteur]); the administration of live attenuated influenza vaccine (LAIV) in egg-allergic individuals; and vaccine effectiveness (VE) of LAIV and inactivated influenza vaccine. Following the review and analysis of this information, the IWG proposed updated recommendations for vaccine use to $\mathrm{NACl}$, based on NACl's evidence-based process for developing recommendations (7). $\mathrm{NACl}$ critically appraised the available evidence and approved the specific recommendations brought forward. The evidence review regarding Fluzone ${ }^{\circledR}$ High-Dose is published separately (8). The rationale and relevant considerations for all the updated recommendations are included in the full Statement for 2016-2017 (4) and the two addenda to the 2016-2017 Statement on LAIV use $(5,6)$.

\section{Results}

New for the 2016-2017 influenza season:

\section{Adults with neurologic or neurodevelopment conditions}

As of 2015-2016, children and adolescents with neurologic or neurodevelopment conditions, including seizure disorders, febrile seizures and isolated developmental delay, have been included in the high-risk group for whom influenza vaccine is particularly recommended. Based on preliminary review of the literature and expert opinion, and consistent with other countries' recommendations, NACI now includes adults with neurologic or neurodevelopment conditions in the high-risk group for whom influenza vaccine is particularly recommended. From the preliminary review, it was noted that the odds ratios for influenza complications in patients with neurologic conditions in comparison to those without in the reviewed studies ranged from 1.57 (pneumonia: 95\% confidence interval [Cl], 1.05 to 2.36) to 19.11 (intensive care unit admission: $95 \% \mathrm{Cl}, 3.92$ to 93.22 ) and 22.2 (hospitalization: 95\% Cl, 2.6 to 186.0) (9-11). The conditions identified as risk factors in the studies reviewed include neuromuscular, neurovascular, neurodegenerative, neurodevelopmental conditions and seizure disorders.

The preliminary literature review findings, rationale, and updated $\mathrm{NACl}$ recommendation for the inclusion of adults with neurologic or neurodevelopment conditions are published in the 2016-2017 Statement (4).

\section{New high-dose, trivalent inactivated influenza vaccine (Fluzone ${ }^{\circledR}$ High-Dose [Sanofi Pasteur])}

Fluzone ${ }^{\circledR}$ High-Dose influenza vaccine has been approved for use in Canada in adults 65 years of age and older. Fluzone ${ }^{\circledR}$ High-Dose is a trivalent inactivated influenza vaccine (TIV) containing $60 \mu \mathrm{g}$ of haemagglutinin (HA) per strain (compared to $15 \mu \mathrm{g} \mathrm{HA}$ per strain in a standard dose), administered as a $0.5 \mathrm{~mL}$ dose by intramuscular injection. Based on the available evidence, $\mathrm{NACl}$ concludes that there is evidence that high-dose TIV should provide superior protection compared with standard-dose TIV for adults 65 years of age and older. This superior relative protection compared to standard-dose TIV appears to increase with increasing age over 65 years. Considering the burden of disease associated with influenza $A(\mathrm{H} 3 \mathrm{~N} 2)$ and the evidence of superior efficacy of high-dose TIV compared to standard-dose TIV, it appears that high-dose TIV would provide the greatest benefit to people 65 years of age and older.

A complete literature review of the Fluzone ${ }^{\circledR}$ High-Dose influenza vaccine for adults 65 years of age and older is published separately (8) and the full $\mathrm{NACl}$ rationale and recommendations on its use are published in the 2016-2017 Statement (4).

\section{Administration of LAIV to egg-allergic individuals}

The safety of LAIV in egg-allergic individuals has now been studied in more than 1,100 children and adolescents (2-18 years of age) in the United Kingdom and Canada (12-14). After careful review of recently published studies, NACl concludes that egg-allergic individuals may be vaccinated against influenza using the low ovalbumin-containing LAIV licensed for use in Canada. The full dose of LAIV may be used without prior vaccine skin test and in any settings where vaccines are routinely administered. LAIV also appears to be well tolerated in individuals with a history of stable asthma or recurrent wheeze; however, it remains contraindicated for individuals with severe asthma (defined as currently on oral or high-dose inhaled glucocorticosteroids or active wheezing) or for those with medically-attended wheezing in the seven days prior to immunization.

The literature review on the safety of LAIV in egg-allergic individuals and updated $\mathrm{NACl}$ recommendation on the administration of LAIV to egg-allergic individuals are published in an Addendum to the 2016-2017 Statement (5).

\section{Updated NACI recommendations for the use of LAIV in children 2-17 years of age}

After careful review of available studies from the last several influenza seasons, $\mathrm{NACl}$ concludes that the current evidence is consistent with LAIV's providing comparable protection against influenza to that afforded by inactivated influenza vaccine in various jurisdictions and has revised its recommendations on the use of influenza vaccine in children 2-17 years of age:

1. In children without contraindications to the vaccine, any of the following vaccines can be used: quadrivalent LAIV, quadrivalent inactivated influenza vaccine (QIV) or TIV.

2. The current evidence does not support a recommendation for the preferential use of LAIV in children and adolescents 2-17 years of age.

Given the burden of influenza B disease in children and the potential for lineage mismatch between the predominant circulating strain of influenza $\mathrm{B}$ and the strain in a trivalent vaccine, $\mathrm{NACl}$ continues to recommend that a quadrivalent formulation of influenza vaccine be used in children and adolescents 2-17 years of age. If a quadrivalent vaccine is not available, TIV should be used.

The observational study data reviewed highlight the challenge in interpreting the VE of LAIV and inactivated influenza vaccine when point estimates by influenza subtype are derived based on small sample sizes associated with wide confidence intervals. Therefore, in making its recommendation, $\mathrm{NACl}$ recognizes the need to continue to monitor the data on the VE of LAIV closely by influenza subtype and the relative effectiveness of LAIV compared to inactivated influenza vaccine. $\mathrm{NACl}$ has identified the need for further research to address current knowledge gaps:

3. $\mathrm{NACl}$ strongly encourages further multidisciplinary (e.g., epidemiology, immunology, virology) research to investigate the reasons for the discordant 2015-2016 VE estimates between studies and explanations for poor LAIV effectiveness against $A(H 1 N 1) p d m 09$ reported in some studies.

4. NACl strongly recommends that sufficient resources be provided to enhance influenza-related research and sentinel surveillance systems in Canada to improve the evaluation of influenza vaccine efficacy and effectiveness to provide the best possible evidence for Canadian influenza vaccination programs and recommendations.

Further details and rationale in support of the updated $\mathrm{NACl}$ recommendations on the use of LAIV in children 2-17 years of age are published in an Addendum to the 2016-2017 Statement (6). 
Summary of $\mathrm{NACl}$ recommendations for the use of influenza vaccines for the 2016-2017 influenza season

$\mathrm{NACl}$ continues to recommend influenza vaccination for all individuals aged six months and older, with particular focus on people at high risk of influenza-related complications or hospitalization, people capable of transmitting influenza to those at high risk and others as indicated in Table 1.

\section{Table 1: Groups for whom influenza vaccination is particularly recommended}

People at high risk of influenza-related complications or hospitalization

- All pregnant women².

- Adults and children with the following chronic health conditions:

- cardiac or pulmonary disorders (including bronchopulmonary dysplasia, cystic fibrosis and asthma),

- diabetes mellitus and other metabolic diseases,

- cancer, immune compromising conditions (due to underlying disease, therapy or both),

renal disease,

anemia or hemoglobinopathy

neurologic or neurodevelopment conditions ${ }^{3}$,

- morbid obesity (body mass index [BMI] of 40 and over), and

children and adolescents (age six months to 18 years) undergoing treatment for long periods with acetylsalicylic acid, because of the potential increase of Reye's syndrome associated with influenza.

- People of any age who are residents of nursing homes and other chronic care facilities.

- People 65 years of age and older.

- All children six to 59 months of age.

- Aboriginal Peoples.

People capable of transmitting influenza to those at high risk

- Health care and other care providers in facilities and community settings who, through their activities, are capable of transmitting influenza to those at high risk of influenza complications.

- Household contacts (adults and children) of individuals at high risk of influenza-related complications (whether or not the individual at high risk has been immunized):

- household contacts of individuals at high risk, as listed in the section above,

- household contacts of infants under six months of age as these infants are at high risk of complications from influenza but cannot receive influenza vaccine, and

members of a household expecting a newborn during the influenza season.

- Those providing regular child care to children 59 months of age and younger, whether in or out of the home.

- Those who provide services within closed or relatively closed settings to persons at high risk (e.g., crew on a ship).

Others

- People who provide essential community services.

- People in direct contact during culling operations with poultry infected with avian influenza.

1 Updated recommendation noted in bold

2 The risk of influenza-related hospitalization increases with length of gestation (i.e., it is higher in the third than in the second trimester)

${ }^{3}$ These include seizure disorders, febrile seizures and isolated developmental delay in children and neuromuscular, neurovascular, neurodegenerative, neurodevelopmental conditions and seizure disorders in adults, but exclude migraines and neuropsychiatric conditions without neurological conditions
Recommended influenza vaccine options by specific age and risk groups and dosage and route of administration by age are summarized in Tables 2 and 3, respectively.

Table 2: Choice of influenza vaccine for selected age and risk groups (for persons without a contraindication to the vaccine)

\begin{tabular}{|c|c|c|}
\hline $\begin{array}{l}\text { Recipient } \\
\text { by age } \\
\text { group }\end{array}$ & $\begin{array}{l}\text { Vaccine types } \\
\text { available for } \\
\text { use }\end{array}$ & Comments \\
\hline $\begin{array}{l}\text { Children 6-23 } \\
\text { months of } \\
\text { age }\end{array}$ & $\begin{array}{ll}\text { - } & \text { TIV } \\
\text { - } & \text { QIV } \\
\text { - } & \text { ATIV }\end{array}$ & $\begin{array}{l}\text { TIV, QIV and ATIV are authorized for this } \\
\text { age group. } \\
\text { NACI recommends that, given the } \\
\text { burden of influenza B disease, QIV } \\
\text { should be used. If QIV is not available, } \\
\text { either unadjuvanted or adjuvanted TIV } \\
\text { should be used. }\end{array}$ \\
\hline $\begin{array}{l}\text { Children 2-17 } \\
\text { years of age }\end{array}$ & $\begin{array}{ll}\text { - } & \text { TIV } \\
\text { - } & \text { QIV } \\
\text { - } & \text { Quadrivalent } \\
& \text { LAIV }\end{array}$ & $\begin{array}{l}\text { In children without contraindications } \\
\text { to the vaccine, any of the following } \\
\text { vaccines can be used: LAIV, QIV, or TIV. } \\
\text { The current evidence does not support } \\
\text { a recommendation for the preferential } \\
\text { use of LAIV in children and adolescents } \\
2-17 \text { years of age. } \\
\text { Given the burden of influenza B } \\
\text { disease in children and the potential } \\
\text { for lineage mismatch between the } \\
\text { predominant circulating strain of } \\
\text { influenza B and the strain in a trivalent } \\
\text { vaccine, NACI continues to recommend } \\
\text { that a quadrivalent formulation of } \\
\text { influenza vaccine be used in children } \\
\text { and adolescents } 2-17 \text { years of age. If a } \\
\text { quadrivalent vaccine is not available, TIV } \\
\text { should be used. } \\
\text { LAIV is not recommended for children } \\
\text { with immune compromising conditions. } \\
\text { LAIV, TIV or OIV can be used in children } \\
\text { with chronic health conditions, including } \\
\text { asthma that is not severe2, and cystic } \\
\text { fibrosis without immune suppression. }\end{array}$ \\
\hline $\begin{array}{l}\text { Adults } 18-59 \\
\text { years of age }\end{array}$ & $\begin{array}{ll}\text { - } & \text { TIV } \\
\text { - } & \text { QIV } \\
\text { - } & \text { Quadrivalent } \\
& \text { LAIV }\end{array}$ & $\begin{array}{l}\text { TIV and QIV are the recommended } \\
\text { products for adults with chronic health } \\
\text { conditions. } \\
\text { TIV and QIV, instead of LAIV, are } \\
\text { recommended for health care workers. } \\
\text { LAIV is not recommended for adults with } \\
\text { immune compromising conditions. }\end{array}$ \\
\hline $\begin{array}{l}\text { Adults } 60-64 \\
\text { years of age }\end{array}$ & $\begin{array}{ll}\text { - TIV } \\
\text { - } \text { OIV }\end{array}$ & $\begin{array}{l}\text { TIV and QIV are authorized for use in } \\
\text { this age group. }\end{array}$ \\
\hline $\begin{array}{l}\text { Adults } 65 \\
\text { years of age } \\
\text { and older }\end{array}$ & $\begin{array}{ll}\text { - } & \text { TIV } \\
\text { - } & \text { OIV } \\
\text { - } & \text { ATIV } \\
\text { - } & \text { High-dose TIV }\end{array}$ & $\begin{array}{l}\text { Given the burden of Influenza A(H3N2) } \\
\text { disease and evidence of better efficacy } \\
\text { in this age group, it is expected } \\
\text { that high-dose TIV should provide } \\
\text { superior protection compared with the } \\
\text { standard-dose intramuscular vaccine } \\
\text { for older adults. }\end{array}$ \\
\hline $\begin{array}{l}\text { Pregnant } \\
\text { women }\end{array}$ & $\begin{array}{l}\text { - TIV } \\
\text { - OIV }\end{array}$ & $\begin{array}{l}\text { LAIV is not recommended because of } \\
\text { the theoretical risk to the fetus from } \\
\text { administering a live virus vaccine. }\end{array}$ \\
\hline
\end{tabular}

Abbreviations: ATIV, adjuvanted trivalent inactivated influenza vaccine; LAIV, live attenuated influenza vaccine (quadrivalent formulation): OIV quadrivalent inactivated influenza vaccine; TIV, trivalent inactivated influenza vaccine

Updated recommendations noted in bold

${ }^{2} \mathrm{An}$ individual with severe asthma is defined as someone who is currently on oral or high-dose inhaled glucocorticosteriods, is active wheezing, or has had medically-attended wheezing in the seven days prior to vaccination 
Table 3: Recommended influenza vaccine dosage and route, by age, for the 2016-2017 influenza season

\begin{tabular}{|c|c|c|c|c|}
\hline $\begin{array}{l}\text { Age } \\
\text { group }\end{array}$ & $\begin{array}{l}\text { TIV without } \\
\text { adjuvant or } \\
\text { QIV IM }{ }^{1}\end{array}$ & $\begin{array}{c}\text { MF59- } \\
\text { adjuvanted } \\
\text { TIV (Fluad } \\
\text { Pediatric }^{\text {TM }} \text { or } \\
\text { Fluad }^{\circledR} \text { ) IM }\end{array}$ & $\begin{array}{l}\text { LAIV (FluMist }^{\circledR} \\
\text { Quadrivalent) } \\
\text { IN }\end{array}$ & $\begin{array}{l}\text { Number } \\
\text { of doses } \\
\text { required }\end{array}$ \\
\hline $\begin{array}{c}\text { 6-23 } \\
\text { months }\end{array}$ & $0.5 \mathrm{~mL}^{2}$ & $0.25 \mathrm{~mL}$ & - & 1 or $2^{3}$ \\
\hline $\begin{array}{c}2-8 \\
\text { years }\end{array}$ & $0.5 \mathrm{~mL}$ & - & $\begin{array}{r}0.2 \mathrm{~mL}(0.1 \mathrm{~mL} \\
\text { per nostril) }\end{array}$ & 1 or $2^{3}$ \\
\hline $\begin{array}{l}9-17 \\
\text { years }\end{array}$ & $0.5 \mathrm{~mL}$ & - & $\begin{array}{r}0.2 \mathrm{~mL}(0.1 \mathrm{~mL} \\
\text { per nostril) }\end{array}$ & 1 \\
\hline $\begin{array}{l}18-59 \\
\text { years }\end{array}$ & $0.5 \mathrm{~mL}$ & & $\begin{array}{r}0.2 \mathrm{~mL}(0.1 \mathrm{~mL} \\
\text { per nostril) }\end{array}$ & 1 \\
\hline $\begin{array}{l}60-64 \\
\text { years }\end{array}$ & $0.5 \mathrm{~mL}$ & & - & 1 \\
\hline $\begin{array}{l}65 \\
\text { years } \\
\text { and } \\
\text { older }\end{array}$ & $0.5 \mathrm{~mL}$ & $0.5 \mathrm{~mL}$ & - & 1 \\
\hline
\end{tabular}

Abbreviations: IM, intramuscular; IN, intranasal; LAIV, live attenuated influenza vaccine (quadrivalent formulation); OIV, quadrivalent inactivated influenza vaccine;

TIV, trivalent inactivated influenza vaccine

${ }^{1}$ Influvac ${ }^{\circledast} 18$ years and older, Fluviral ${ }^{\circledR}$ six months and older, Agriflu ${ }^{\oplus}$ six months and older, Vaxigrip ${ }^{\circledR}$ six months and older, Fluzone ${ }^{\circledR}$ six months and older, Fluzone ${ }^{\circledR}$ High-Dose 65 years and older, Flulaval ${ }^{\circledR}$ Tetra six months and older, Fluzone ${ }^{\circledR}$ Quadrivalent six months and older

${ }^{2}$ This information differs from the product monograph

${ }^{3}$ Children six months to less than nine years of age who have never received the seasonal influenza vaccine require two doses of influenza vaccine, with a minimum interval of four weeks between doses. Eligible children less than nine years of age who have properly received one or more doses of seasonal influenza vaccine in the past should receive one dose per influenza vaccination season thereafter

\section{Conclusion}

$\mathrm{NACl}$ continues to recommend annual influenza vaccination for all individuals aged six months and older (noting product-specific age indications and contraindications), with particular focus on people at high risk of influenza-related complications or hospitalization, including all pregnant women, people capable of transmitting influenza to those at high risk and others as indicated.

\section{Acknowledgements}

NACl members: I. Gemmill (Chair), C. Quach-Thanh (Vice-Chair), N. Dayneka, S. Deeks, B. Henry, S. Marchant-Short, M. Salvadori, N. Sicard, W. Vaudry, D. Vinh, R. Warrington

\section{Former NACl member: D. Kumar}

Liaison representatives: J. Blake (Society of Obstetricians and Gynaecologists of Canada), J. Brophy (Canadian Association for Immunization Research and Evaluation), A. Cohn (Centers for Disease Control and Prevention, United States [CDC]), J. Emili (College of Family Physicians of Canada), M. Lavoie (Council of Chief Medical Officers of Health), C. Mah (Canadian Public Health Association), D. Moore (Canadian Paediatric Society),
A. Pham-Huy (Association of Medical Microbiology and Infectious Disease Canada), E. Sartison (Canadian Immunization Committee $[\mathrm{CIC}])$

Former liaison representative: C. Weinbaum (CDC)

Ex-officio representatives: K. Barnes (National Defence and the Canadian Armed Forces), G. Charos (Centre for Immunization and Respiratory Infectious Diseases [CIRID], Public Health Agency of Canada [PHAC] and CIC), G. Coleman (Biologics and Genetic Therapies Directorate, Health Canada [HC]), J. Gallivan (Marketed Health Products Directorate, HC), J. Pennock (CIRID, PHAC), R. Pless (CIRID, PHAC), T. Wong (First Nations and Inuit Health Branch, $\mathrm{HC}$ )

$\mathrm{NACl}$ also gratefully acknowledges the contribution of: L. Grohskopf (CDC), J. Langley (Influenza Working Group [IWG]), J. McElhaney (IWG), A. McGeer (IWG), V. Meikle (CIRID, PHAC), R. Stirling (CIRID, PHAC), B. Warshawsky (IWG), E. Wong (CIRID, $\mathrm{PHAC}$ ), and J. Xiong (IWG)

\section{Funding}

The work of $\mathrm{NACl}$ is supported by the Public Health Agency of Canada.

\section{Conflict of Interest}

None.

\section{References}

1. Statistics Canada. The 10 leading causes of death, 2011 [Internet]. Ottawa: Statistics Canada; 2014 [updated 2015 July 27; cited 2016 Aug 16]. http://www.statcan.gc.ca/ pub/82-625-x/2014001/article/11896-eng.htm.

2. Schanzer DL, McGeer A, Morris K. Statistical estimates of respiratory admissions attributable to seasonal and pandemic influenza for Canada. Influenza Other Respir Viruses 2013;7(5):799-808.

3. Schanzer DL, Sevenhuysen C, Winchester B, Mersereau T. Estimating influenza deaths in Canada, 1992-2009. PLoS One 2013;8(11):e80481.

4. National Advisory Committee on Immunization (NACl). Canadian Immunization Guide Chapter on Influenza and Statement on Seasonal Influenza Vaccine for 2016-2017 [Internet]. Ottawa: PHAC; 2016 [updated 2016 May 10; cited 2016 Aug 16]. http://www.phac-aspc.gc.ca/naci-ccni/flu2016-grippe-eng.php.

5. National Advisory Committee on Immunization (NACl). Addendum - LAIV use in egg allergic individuals [Internet]. Ottawa: PHAC; 2016 [updated 2016 Aug 30]. http://www.phac-aspc.gc.ca/naci-ccni/flu2016-grippe-addendum-eggs-oeufs-eng.php.

6. National Advisory Committee on Immunization (NACl). Addendum - LAIV use in children and adolescents [Internet]. Ottawa: PHAC; 2016 [updated 2016 Aug 30]. http://www.phac-aspc.gc.ca/naci-ccni/flu2016-grippe-addendum-children-enfants-eng.php. 
7. National Advisory Committee on Immunization (NACl). Evidence-based recommendations for immunization - Methods of the National Advisory Committee on Immunization. Can Comm Dis Rep 2009;35:ACS-1. http:// www.phac-aspc.gc.ca/publicat/ccdr-rmtc/09vol35/acs-1/ index-eng.php.

8. National Advisory Committee on Immunization (NACl). A review of the literature of high dose seasonal influenza vaccine for adults 65 years and older [Internet]. Ottawa: PHAC; 2016 [updated 2016 April 11; cited 2016 Aug 16]. http://www.phac-aspc.gc.ca/naci-ccni/influenza-vaccine65-plus-vaccin-contre-la-grippe-65-plus-eng.php.

9. Gilca R, De Serres G, Boulianne N, Ouhoummane N, Papenburg J, Douville-Fradet M, et al. Risk factors for hospitalization and severe outcomes of 2009 pandemic H1N1 influenza in Quebec, Canada. Influenza Other Respir Viruses 2011;5(4):247-55.

10. Mertz D, Kim TH, Johnstone J, Lam PP, Science M, Kuster $\mathrm{SP}$, et al. Populations at risk for severe or complicated influenza illness: Systematic review and meta-analysis. BMJ 2013;347:f5061.
11. Poeppl W, Hell M, Herkner H, Stoiser B, Fritsche G, Schurz-Bamieh N, et al. Clinical aspects of 2009 pandemic influenza $A(H 1 N 1)$ virus infection in Austria. Infection 2011;39(4):341-52.

12. Turner PJ, Southern J, Andrews NJ, Miller E, Erlewyn-Lajeunesse M; SNIFFLE Study Investigators. Safety of live attenuated influenza vaccine in atopic children with egg allergy. J Allergy Clin Immunol 2015;136(2):376-81.

13. Turner PJ, Southern J, Andrews NJ, Miller E, Erlewyn-Lajeunesse M; SNIFFLE-2 Study Investigators. Safety of live attenuated influenza vaccine in young people with egg allergy: Multicenter prospective cohort study. BMJ 2015;351:h6291.

14. Des Roches A, Samaan K, Graham F, Lacombe-Barrios J, Paradis J, Paradis L, et al. Safe vaccination of patients with egg allergy by using live attenuated influenza vaccine. J Allergy Clin Immunol Pract 2015;3(1):138-9.

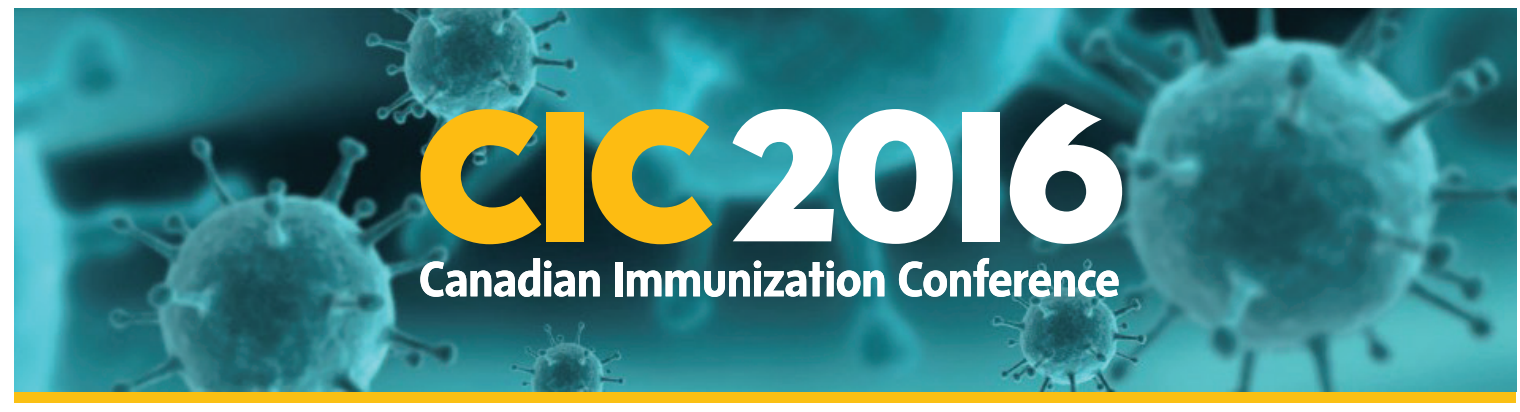

\title{
Canadian Immunization Conference 2016
}

\author{
December 6-8, 2016 | Shaw Centre \\ Ottawa, Ontario, Canada
}

\section{Early Bird Rate available until Sept. 30, 2016}

\section{REGISTER NOW cic-cci.ca/registration}

